\title{
Editorial
}

\section{Know thy changing consumer}

Journal of Brand Management (2008) 15, 227-231. doi:10.1057/palgrave.bm.2550141

\section{SAVVY CONSUMERS}

'Know thy consumer' is a basic principle of brand management and of marketing more generally. This principle is as important today as it has ever been. But consumers aren't a fixed target. Consumers change: existing consumers of a brand develop new needs, change their preferences, alter their habits and acquire new skills for engaging in purchasing and consumption; fresh consumers come into new and established markets, with their own needs, preferences and skills. Pundits talk of contemporary consumers as better informed and connected, more marketing literate and savvier, than in the past, and as being more empowered. Some commentators even describe this as a new economic order-an era of consumer-centric commerce. ${ }^{1,2}$ Assuming the pundits are correct, it would be surprising if these momentous changes didn't have implications for the way consumers think about brands and the way brands will be managed in future. The Buyer Centric Commerce Forum puts it this way: "'person-centric commerce" is set to transform how individuals and organisations interact and transact, and change the way our economy works. Individuals in all their roles"consumer", "employee", "citizen"-will benefit greatly from person centric services. So will the organisations that serve them' ${ }^{3}$

The contemporary savvy consumer is seen as someone who combines areas of competency (particularly technological sophistication, network competency and marketing/advertising literacy) with empowerment (especially self-confidence and self-efficacy). ${ }^{4}$ Before looking at the implications of this for brand management it is worth taking a closer look at these components of consumer savvy. Competency refers to practical skills and acquired knowledge to respond to a constantly changing environment. It is seen in the technological sophistication of consumers: they are ready and willing to adopt new technologies (everything from SMS to interactive, participatory iCinema) and they are comfortable multi-tasking with their technological toolkit (seamlessly moving between PC access to websites, sending SMS-messages, retrieving emails from their BlackBerry and being guided by GPS navigation devices). Competency is also seen in the way consumers make use of their networks: the capacity to harness a network of useful personal contacts (to acquire up-to-date product information, to hear about word-ofmouth recommendations and to make more informed choices) and to tap into the online mega-net (with its bulletin boards, chat-rooms, blogs, social gaming sites, virtual communities and word-ofweb information exchange). Competency is further manifest through marketing/ advertising literacy-the fact that consumers are familiar with the ideas, objectives and methods of marketing, advertising and marketing communications. This is evident in the way consumers understand and use marketing terminology, the way they closely follow developments in the media business, their capacity to deconstruct and reconstruct marcoms and their readiness to offer judgments about products, attributes, value and 
levels of service. Added to which is their willingness to poke fun at business, such as the irreverent YouTube spoofs of iconic ad campaigns and more sustained attacks that are to be found on AdBuster-style anti-branding sites. Such sophisticated literacy gives consumers greater control over what they see, hear and read, especially when control is combined with enabling technologies (the panoply of enablers that extends from the inter-net to podcasts and webcasts, from personal shopping assistants to iPods and iPhones). ${ }^{5,6}$

Empowered by access to information, but time-poor, consumers are driven by value-seeking-not just the value that accrues from consuming brands, but also value in terms of quality interactions with the organisation behind the brands. As such, they seek value-for-time, value-forattention and value-for-access to their personal information. ${ }^{7}$ The democratisation of access to information means that consumers have enhanced self-confidence in their ability to perform behaviours related to consumption - just think of the aptitude and astuteness of consumers when they engage in online grocery shopping, online travel booking and online gift-giving. Self-confidence is in many cases fully justified-compared to conventional technologies, user-directed ones give consumers remarkable levels of control (web users, for instance, decide which websites to visit, bookmark and revisit, they choose whether to navigate thoroughly or fleetingly, they determine if interaction should occur, how often, on what terms and for what purpose). Consumers have the ability and the confidence to 'call the shots'.

Savviness isn't purely about technology. Indeed, face-to-face interpersonal networks remain important for social chit-chat and marketing literacy can be as much about Hello-style magazine gossip as about an understanding of the ramifications of digital technologies in the media industry. Nevertheless, technology provides a platform for many of the changes. And the way consumers engage with technology is changing too. Many of the new technologies are user-directed (website navigation, e-kiosks, iTV, iPhones and so forth). User-direction requires the consumer to shift from reliance on declarative knowledge (factual information about attributes, terminology, evaluative criteria, facts and usage situations in an area of interest) to more reliance on procedural knowledge (knowledge of rules and procedures for action in making decisions and taking action in an area of interest); if you like, a shift from the old static view of knowledge to a dynamic, contemporary view of knowledge. Consumers are skilled problem-solvers, exhibiting confidence in their procedural knowledge, even in the absence of sound declarative knowledge. ${ }^{8}$ Think of those installation and operating instructions that accompany any new gadget purchaseconsumers regard them as something to be read as a last resort, if trial and error and intuition have failed. Rather like the use of 'cheats' in the online gaming world, nowadays there is something mildly embarrassing about having to look at instruction sheets.

\section{RESPONSIVE BRAND MANAGEMENT}

The impact on brand management of changing consumers is evident in various ways. Not least is the willingness of consumers to adopt new technologies in droves, creating staggering opportunities for certain players to become megabrands, from online stars like Google and Yahoo! to re-packaged, re-invigorated, hybrid off/online businesses such as the 
BBC. In parallel, there is the stellar growth of comparative newcomers such as social networking sites FaceBook and MySpace and online gaming brands like JagX/ RuneScape. At a time when the big six US television networks have recorded absolute falls in ad spend, online social network ad spending is forging ahead-a current spend of $\$ 525,000$ on MySpace and $\$ 200,000$ on other general social network sites like Facebook, Bebo, Piczo and Friendster, and all the signs are that these sums will grow exponentially in the coming years. ${ }^{9}$ This phenomenon is not entirely new-there were plenty of technological stars in the dot.com era, but even at the time we sensed that many were only ever going to be shooting stars. ${ }^{10}$ By contrast, the mega-brands of today are committing to the long-haulas far as that is feasible in intensely open and competitive markets.

Novel brand attributes come into play: consumers of an online social network site want to share content, communicate easily, interact in real-time and profile themselves (as often as not by providing fictionalised portrayals). Ease of use, speed and interactivity are valued attributes. Any brand that cannot match consumer expectations in terms of these attributes is likely to find its future very bleak. Information diffusion about brands is rapid through offline and online word-of-mouth communication, through marketer-controlled and uncontrolled buzz and viral communications. Positive news travels faster, but so too does negative news. Deceits and lies are uncovered, blogged and publicised. Exposure in cyberspace is full-frontal.

More and more opportunities exist for consumers to engage with brandsthrough brand communities, product sites, forums, blogs. But, simultaneously, there may be less and less reason to engage- why should a consumer go to the trouble of engaging when perhaps all that he or she wants is a value-for-money product that will perform satisfactorily? Technological sophistication and network competency combine to reduce information asymmetry which has traditionally been biased toward the firm, giving the upper hand to consumers. ${ }^{11}$ This conundrum is not fully appreciated by the marketing community. Indeed, among marketers there is a tendency to focus on the upside rather than dwell on the downside. Many marketers even fail to recognise that there might be a downside. Organisations that serve consumers, employees and citizens in the world of person-centric commerce will be beneficiaries-so say the advocates ${ }^{12}$ — but along the way there will be losers and casualties, including some businesses that over-estimate the desire of their consumers for engagement at the expense of offering basic value-for-money.

\section{DIFFERENTIALLY SAVVY CONSUMERS}

Important as all these impacts are, arguably the biggest challenge for brand managers is how to contend with differences among consumers. Consumers change, but not all at the same pace. Not all consumers are equally savvy. Not all are equally empowered. Some consumers may display competence in one area but not in another-think of the skilled computer operator who is inept at, or indifferent to, mobile phone usage. The new technological mega-brands appeal to the needs and aspirations of some consumers more than others. Novel attributes are more important to certain consumers than others. Online, there are consumers who fear for their privacy, whereas others flagrantly disregard their privacy and the privacy of others. Information diffuses 
faster through some groups than others. Engagement is desired by some and shunned by others.

In part this is generational. The underthirties 'are more savvy, more materialistic, more media-saturated and more impatient than any generation that's preceded them'. ${ }^{13}$ Gen Y-the so-called options generation-wants the freedom to exercise choice. Among Australian Gen Ys, 99 per cent own a mobile phone, 99 per cent use the internet regularly (up to six hours a day), almost 90 per cent own a computer, 82 per cent own an MP3 player and 32 per cent are prepared to admit to downloading music illegally in the previous four weeks. ${ }^{14}$ Evidence, if evidence is needed, that these consumers are exercising choice. Further down the generational ladder, teens, tweens and Gen $M$ know nothing but the exercise of choice, particularly when it comes to new technologies. A quarter of Australian 6-11-year-olds now own a mobile phone, using it for several hours each week, and they are also increasingly heavy online users, claiming it is indispensable for homework research and online assignments, although social uses figure prominently too (online games, email, entertainment information, instant messaging).${ }^{15}$ In high school playgrounds, the brands that dominate conversation are not necessarily old-timers like Disney, but the interactive, multi-player, adventure and fantasy games-RuneScape, World of Warcraft and Maple Story.

But the picture is more complicated than this: it isn't simply that the young are savvy and the old aren't. Indeed, many in the older generations are savvy and technologically sophisticated. Moreover, older consumers are striving to be younger. " "Sixty is the new 50", they want to assure us, because it reinforces the conviction that they are much "younger" than their parents were at the same age: they eat younger, dress younger, act younger, think younger, feel younger'. ${ }^{16}$ Perhaps the real difference between the generations is Gen Y and Gen M take digital, interactive technologies for granted- they are cyberspace natives-whereas older generations are like immigrants who have, at differing rates and with differing abilities, had to learn about this brave new world. ${ }^{17}$

Superimposed on these generational differences are variations in gender, socioeconomic status, access to technology, educational attainment and ability-all the components that go to create, on the one hand, digital communities, and, on the other hand, digital divides.

\section{DIFFERENTIALLY RESPONSIVE BRAND MANAGEMENT}

One view of these differences among consumers is that they coalesce into neat segments that can be served by niche brands. Marketers have in mind an engagement model where brands are seen as highly customised, and therefore highly relevant, to particular groups of consumers, where there is an emotional connection or bond between consumers and brands, accompanied by strong socio-emotional relationships in physical and virtual space. Relationships are at the core of this engagement model. The gamut of marcoms then follows from the existence of these relationships, not the other way round. 'Brand engagement drives directly to what the marketer is trying to do-get the customer involved with the brand'. ${ }^{18}$ However, the reality may be far less comforting for those in brand management - a fragile, fractured and fragmented landscape, where it is increasingly difficult for brands to be neatly aligned with well-defined, identifiable and stable groups of consumers. What we known for sure 
is that in this landscape there is an even greater imperative to 'know thy consumer'.

\section{Mark Uncles Editorial Board}

\section{References}

(1) Mitchell, A. (2004) 'The buyer-centric revolution: The rise of reverse direct', Interactive Marketing, Vol. 5, No. 4, pp. 345-358.

(2) Buyer Centric Commerce Forum. (2007) ‘Person centric commerce', Right Side Up website (http://www.rightsideup.net/index.html, accessed 1st December, 2007).

(3) Buyer Centric Commerce Forum. (2007) ref. 2 above.

(4) Macdonald, E. K. and Uncles, M. D. (2007) 'Consumer savvy: Conceptualisation and measurement', Journal of Marketing Management, Vol. 23, No. 5-6, pp. 497-517.

(5) Macdonald and Uncles, ref. 4 above.

(6) Uncles, M. D. (2006) 'Understanding retail customers', in Krafft, M. and Mantrala, M. K. (eds) 'Retailing in the 21st Century', Springer, Heidelberg, Germany.

(7) Lawer, C. and Knox, S. (2004) 'Reverse marketing, consumer value networks and the new brand intermediaries', in Chang, Y. S. (ed.) 'Value Network and ICT Symbiosis: Issues and Applications for Operational Excellence', Kluwer, New York, NY.

(8) Page, K. and Uncles, M. D. (2004) 'Consumer knowledge of the worldwide web: Conceptualization and measurement', Psychology \& Marketing, Vol. 21, No. 8, pp. 573-591.

(9) AMA. (2007) '2007 Marketing Fact Book', Marketing News, 15 July, pp. 23-32.

(10) Uncles, M. D. (2001) 'Editorial: Interactive electronic marketing and brand management', Journal of Brand Management, Vol. 8, No. 4/5, pp. 245-254.

(11) Mitchell, ref. 1 above.

(12) Buyer Centric Commerce Forum, ref. 2 above.

(13) Mackay, H. (2007) 'Advance Australia ... Where?', Hachette Australia, Sydney, Australia.

(14) Cincotta, K. (2007) 'Access all areas', BETWeekly, 2 November, pp. 16-22.

(15) Chenery, M. (2007) 'Tales of an eGeneration', AdNews, 2 November, p. 7.

(16) Mackay, ref. 12 above.

(17) Lankshear, C. and Knobel, M. (2006) 'New Literacies: Everyday Practices and Classroom Learning', McGraw-Hill, Berkshire, UK.

(18) Schultz, D. (2007) 'Focus on brand changes rules of engagement', Marketing News, 15 August, p. 7 . 